\title{
Designing and Decision M aking of Transport Chains between China and Germany
}

\author{
Jian TONG $^{1}$ \\ ( ${ }^{1}$ Institute for Transport Economics and Logistics, Vienna University of Economics and Business, A-1090, Austria) \\ Email: jian.tong@wu.ac.at \\ Haitao WEN ${ }^{2}$, Xuemei FAN ${ }^{3}$ \\ $\left({ }^{2}\right.$ and 3 College of Qurtermaster and Technology, Jilin University, Changchun, 130062) \\ Email: wenht@jlu.edu.cn, fxm@jlu.edu.cn \\ Sebastian KUMMER ${ }^{4}$ \\ ( ${ }^{4}$ Institute for Transport Economics and Logistics, Vienna University of Economics and Business, A-1090, Austria) \\ Email: Sebastian.kummer@wu.ac.at
}

\begin{abstract}
Optimization of an international transport chain may contribute significantly to a successful outcome in international trade. The performance of various modes of transport influences the selection of one over others. This paper analyses the transport chain between China and Germany, comparing routes and aiming to identify the best practices and chose the optimal transport mode. Through analysing secondary data, the different means of transport are presented. The SWOT analysis was selected to analyse and compare the competitive operation of the various methods of transport between China and Germany. This helps us understand what determines the selection of one mode of transport mode rather than another; the development of rail transport between China and G ermany should be urged, in addition to the air and sea modes; Price, timing, level of service and relationship with forwarder are vital factors in determining the route option between $\mathrm{China}$ and Germany. More secondary data should be used to validate the research in the future. (Abstract)
\end{abstract}

Index Terms- Decision Making, Transport Chain, China, Germany, E urasian Land Bridge, transport mode, SWOT

\section{INTRODUCTION:}

The last few decades, economic development is characterized by increased globalization. Separated markets have grown together and have become integrated in one global market. Companies have developed into multinationals, spreading out their operations all over the globe. A wide range of products are manufactured in China and from there exported to many parts of the globe. Today's China is the biggest exporter in the global economy. The EU is China's biggest trading partner and on the other hand also China is of utmost importance for the EU since it is its 2nd biggest trading partner after the USA and the main source of imports [19]. Germany is the EU's biggest market and therefore an interesting destination for Chinese exporters and investors.

In fact, China and Germany play key roles in the global economy. While Germany has been called the "world champion" of export, China is becoming Germany's second largest trading partner outside Europe. Since the EU is China's largest trading partner, Germany is vital to Chinese European strategy due to its no.1 market volume in the EU. Both Germany and China are globalized and have open markets. Looking at the world's largest 500 companies, based on statistics of United States Fortune 2009, China and Germany were placed no. 4 with 40 companies and no. 5 with 39 companies respectively after the USA (140), Japan (68) and France (43) [19].

From the total of China's export $4,27 \%$ is destined for Germany [19]. This percentage might sound small but with a total export volume of 1,204 trillion US dollar this is still $\$ 51,41$ billion worth of exports. China is an important export partner for Germany as well. From the total German export $4,5 \%$ is headed towards China [20]. Though China replaced Germany in 2009 as export "world champion", China is exporting lower value-added products than Germany. The research comes as exports in the electronics industry showed China, with $18.5 \%$, still lagging behind Germany (27.3\%), as well as electrical engineering, with $13.4 \%$ [12] [20].

Germany is an EU oriented exporting country. Its most important trading partners are the EU member countries. About three quarters of exports of goods "Made in Germany" were delivered to European countries. The second most important sales market for German goods in 2009 (after the EU) was Asia with around $14 \%$ value [12] [20]. The export value of commodities more than doubled from 1991 to 2005 (from US\$402 billion to US\$977 billion). These clean statistics show us that there is a substantial flow of goods moving between China and Germany and due to China's continues economic growth there will be an increasing demand for transportation services. Another possible mode of transportation between China and Germany is air transport. However, air transport has a very limited capacity and is only an option for a small range of high value products. Is there another way of transport that can be a sustainable alternative to sea or air transport?

Furthermore, logistics in Germany also registered the fastest-growing industry, which has an output value that increased by $4.5 \%$ in the past 10 years. In 2007 the market volume of the logistics industry was $€ 190$ billion, which equals $60 \%$ of the volume of the automobile industry. Thus, logistics in Germany dominates $20 \%$ of the EU market and takes the first place [6]. 
TABLE I. COMPARISON OF INTERNATIONAL TRADE BETWEEN CHINA AND GERMANY

\begin{tabular}{|c|c|c|c|c|c|c|}
\hline $\begin{array}{l}\text { Y ear } \\
2008\end{array}$ & $\begin{array}{c}\text { Summer } \\
\text { (100 mio. } \\
\text { USD) }\end{array}$ & $\begin{array}{c}\text { Export } \\
\text { (100 mio. } \\
\text { USD) }\end{array}$ & $\begin{array}{c}\text { Import } \\
\text { (100 mio. } \\
\text { USD) }\end{array}$ & $\begin{array}{l}\text { Rank } \\
\text { in the } \\
\text { World }\end{array}$ & $\begin{array}{l}\text { share } \\
\text { of the } \\
\% \text { all } \\
\text { export }\end{array}$ & $\begin{array}{l}\text { share } \\
\text { of the } \\
\% \text { all } \\
\text { I mport }\end{array}$ \\
\hline China & 25608 & 14283 & 11325 & $\begin{array}{c}\text { Export } \\
\text { No.2 } \\
\text { Import } \\
\text { No.3 } \\
\end{array}$ & $4.0 \%$ & $4.7 \%$ \\
\hline Germany & 26657 & 14619 & 12038 & $\begin{array}{c}\text { Export } \\
\text { No.1 } \\
\text { Import } \\
\text { No. } 2\end{array}$ & $7.3 \%$ & $3.4 \%$ \\
\hline
\end{tabular}

Source: [12] [22] [24]

Geographically, Germany is located at the centre of the EU. It possesses top class infrastructure with major seaports such as Hamburg and Bremerhaven and large airport hubs such as Frankfurt and Munich. Meanwhile, with the establishment and improvement of a mature and efficient system of motorways and railways and good connection to all of its neighbouring countries, German logistics is becoming the main driver to advance the EU transportation system. In the following paragraphs, the main transport modes between Germany and China are presented.

Air transport: The airport network in Germany is one of the best in the world. There are over 520 airports in Germany in all, including 39 international airports [21]. Frankfurt and Munich are the chief airports for flights to China. Frankfurt is the largest in Germany and one of the most important hubs worldwide, in eighth place according to international airport rankings. Frankfurt airport is also one of the most important transshipment stations between China and other European countries' air transport links. There are direct air transport links between Frankfurt and nine Chinese cities. Table 2 shows an overview of freight between Chinese airports and Frankfurt in 2007.

TABLE II. CARGO VOLUME OF THE FRANKFURT AIRPORT WITH V.R.CHINA

\begin{tabular}{|l|llllll|}
\hline Airport & $\begin{array}{c}\text { Cargo } \\
\text { To }\end{array}$ & From & Sum & $\begin{array}{c}\text { Cargo } \\
\text { Flight } \\
\text { To }\end{array}$ & From & Sum \\
\hline Beijing & 33.564 & 32.022 & 65.586 & 387 & 437 & 824 \\
Chengdu & 58.500 & 176 & 58.676 & 18 & 17 & 35 \\
Guangzhou & 10978 & 3867 & 14.845 & 143 & 141 & 284 \\
Kashi & 0 & 0 & 0 & 2 & 0 & 2 \\
Shanghai & 96.878 & 48.050 & 144.928 & 1.345 & 1.343 & 2.688 \\
Shenyang & 2.110 & 541 & 2.651 & 23 & 23 & 46 \\
Urumqi & 83 & 0 & 83 & 193 & 0 & 193 \\
Hongkong & 99.693 & 38.283 & 137.976 & 1.146 & 1.240 & 2.286 \\
Total & 301.806 & 122.939 & 424.745 & 3.257 & 3.201 & 6.458 \\
Average per & 5.804 & 2.364 & 8.168 & 63 & 62 & 124 \\
week & 5.364 & & & & & \\
\hline
\end{tabular}

Source: Frankfurt Airport 2009 [13]

In addition, the huge imbalance of air commodity transport creates empty backhaul of containers in air transport between China and Germany. While 320,884 tons of air freight travelled from China (including Hong Kong) to Germany, only 118,126 tons were delivered from Germany to China (including Hong Kong) [13]. Seventy-one percent of them were from China to Frankfurt, and 30\% of them were from Frankfurt to China. That means there is a large surplus of exports over imports for China [13] [30]. .

Sea transport: Sea transport is the main mode between China and Germany. Ninety percent of world trade is carried by sea transportation. Both the EU and China are major players in maritime affairs. Furthermore, EU shipping companies control more than $40 \%$ of the world's fleets, and China is the EU's second largest trading partner [9].

As the largest port in Germany, Hamburg is the main port for sea transportation between China and Germany, also used by neighboring countries such as Poland, the Czech Republic, Slovakia, Austria and even the whole Baltic Sea region as their main cargo port. According to statistics, nearly one-third of the containers at Hamburg port were transferred from China (including Hong Kong) in 2008, which amounted to around 3.1 million TEU. The Chinese corporation COSCO, China Shipping Group Company, and Kerry Logistics have established their European HQs in Hamburg as well, which are responsible for the whole of their European business [5].

Rail transport: Currently, there is no direct actual regular running railway transport between Germany and China. Rail transport played a major role in the development of Europe, North America and Japan following the Industrial Revolution [6]; the standard gauge of $1,435 \mathrm{~mm}$ has been adopted for about $60 \%$ of the world's railways, across North America and most of Western Europe. Other gauges have been adopted as well such as the broad gauge $(1,520 \mathrm{~mm})$ in the former Soviet Union accounting for about $17 \%$ of railways. All rail freight from China across the Eurasian Land Bridge between Asia and Europe must pass through Russia [7]. Meanwhile, rail transport plays only a subordinate role so far in China. In fact, only $8 \%$ of freight volumes (normally solids) were transported by the rail network [30].

In the following paragraphs, the several possibilities that influence the development and improvement of land bridge corridors between Asia and Europe are presented.

The New Eurasian Land Bridge, the overland rail link between East Asia and Europe, is a new concept in recent years. The specific route is still under development [1]. Nowadays, 60 countries are involved in Europe-Asia trade, which represents more than $50 \%$ of the world's GDP and $70 \%$ of trade volume and more than $60 \%$ of the world's population. Marine and air transportation cannot meet the increasing business needs [30]. Based on a comparison in terms of time and flexibility, rail transport is an ideal potential for developing an alternative mode. Train is more competitive in time than marine transport, and more cost advantageous than air transport. Moreover, to the landlocked countries of Central Asia, Euro-Asian inland transport would have a leading position [5].

There was a successful experiment in rail transport in the new Eurasian Land Bridge. In 2008, German and Russian railways completed a trial run with a container block-train from Beijing to Hamburg within 15 days, in cooperation with railway operators of China, Mongolia, Belarus and Poland along the Trans-Siberian Railway 
(TSR). The train crossed the railways of five countries: China, Mongolia, Russia, Belarus and Germany [23].

Trans-Asian Railway (TAR) is an $81,000 \mathrm{~km}$ long railway network connecting Asia and Europe. Based on regional integration with 28 countries, transport costs and freight times have been reduced in comparison to sea transport and in the long term, it can be hoped that sea transport may be replaced. In the beginning of 2009 Istanbul, southern Europe and the Chinese east coast were connected successfully. By 2020 the TAR will be constructed over 100,000 km [30][16].

The Transport Corridor Europe-Caucasus-Asia programme (TRACECA) was first initiated by the EU in Brussels in May 1993. TRACECA is a multimodal transport route and restoration of the historic silk route including further development. All ongoing projects were fully evaluated between Asia and the EU [10]. TRACECA is currently at a new stage of its development and has formed into an efficient coordination mechanism of transport cooperation in the region. The EU border is now nearer to the littoral states of the Black and the Caspian Seas due to the entry of new states into the EU. Therefore, it increases possibilities for strengthening ties and cooperation between the TRACECA member states and the European Union [10].

Need to be mentioned here is the Trans-European Network for Transport (TEN-T). TEN-T consists of 30 priority axes and projects, it describes a road, rail, waterbased and air transport network that links the EU member states with each other, as well as with their neighbors. The main objectives of the TEN-T policy is to remove bottlenecks in transport infrastructure, build missing links in trans-European routes and develop a sustainable transport network [31]. The 30 axes are vital transEuropean routes that integrate land, sea and air transport infrastructure components. EU policy makers have realized that an extension of the network to the EU's neighbors is an important issue as well. This is of course of great interest for the development of the Eurasian land bridge.

The Trans-European Rail network (TER) is built on the basis of the Trans-European high-speed rail network and the Trans-European conventional rail network. The rail network is part of the TEN-T, which has been built by the authorities of 16 Central and Eastern Europe (CEE) countries (Austria, Bosnia and Herzegovina, Bulgaria, Croatia, Czech Republic, Georgia, Greece, Hungary, Italy, Lithuania, Poland, Romania, Russian Federation, Slovakia, Slovenia and Turkey) and additionally four observer countries (Belarus, Macedonia, Moldova and Ukraine) which participated in various TER actions. The main objective of TER is to strengthen cooperation with the EU. It is already permitted to interconnect via ports of common interest with short sea shipping and inland waterways standards for the rail network.

In the globalization process of Chinese enterprises in Europe, China needs to choose some countries for strategic logistics centers. The EU will be a unified market in the near future, which allows free transportation of goods, which is ideal for Chinese exporters. Thus, Germany as a gateway to the EU will certainly play a vital role in Chinese global logistics systems in the future. The purpose of this paper is to investigate the transport mode and the decision making that led to its selection between China and Germany.

In this research background, the authors will discuss the following research questions:

1. How can be presented the current developments, constraints and challenges as well as the future developments of the various transport situations between China and Germany?

2. Which possible method could be used to compare the different transport modes between China and Germany?

3. Which criteria can be identified in designing and decision-making of transport chains between China and Germany?

\section{LITERATURE REVIEW}

The research literature on international logistics is mostly focused on the USA and Japan [4], and that focusing on countries like North America and European countries is extensive. Asia Pacific countries, such as China, Korea etc., are covered more generally as representative of "Far East" logistics [3]. The Netherlands is widely discussed, with Rotterdam being identified as "the gateway to Europe" [5]. Indeed the Netherlands has spent 30 years building logistics facilities in Rotterdam port and in Schiphol airport [15]. Little research refers to transport between China and Germany.

In this research, transport chain means the movement of goods, including both the direct transport mode and intermodal transport as a sequence of separate stages [14]. A transport chain is usually long-distance haulage which is connected with either a unimodal or multimodal sequence of traffic from a point of origin to a point of delivery. For trade between countries it is mainly a road sea - road or a road - air - road sequence. Within Europe other combinations such as road - rail - road or road surface water - road transport are also common [25] [30].

Transport chains could bear some major problems that make them sometimes inadequate to meet customer's requirements. These problems could occur for unimodal or multimodal chains. Within such a chain the goods have to be transported from their origin to a terminal via road transport. After arrival at the terminal the goods were transferred to either a vessel or an aircraft, resulting in handling processes and, therewith, in disruptions. Ship or airplane is then covering the main distance followed by a second shift back to road transport which delivers the goods to their final destination. Figure 1 shows a usual intermodal transport chain [14].

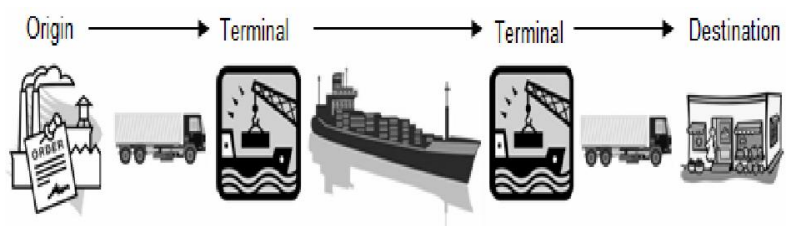

Figure 1: Intermodal Transport Chain (Source: Authors with reference to Slater (2007) [14])

Taking account of the Chinese economy, this continues to grow at a remarkable rate. It is expected that the demand for transportation services will rise steadily. Transport chains are faced, or will be faced with several capacity limits because of congestions, higher fuel prices, 
several bottlenecks and volatile freight rates, etc., which have a negative effect on both transit time and schedule reliability.

Secondly, the security threats have a negative impact on the transit time, schedule reliability and the freight costs of intermodal transport chains. This impact is most recognizable on transport chains between the Far East and Europe since modern pirates are most active on shipping routes between Asia and Europe.

Thirdly, the imbalance in global trade creates the problem of the empty container backhaul. To fulfill the demand for empty containers, shipping companies either organize a backhaul of empty containers from surplus areas or purchase new containers. Both methods result in higher costs and reduce the efficiencies created by intermodal transport in the first place. Besides the tremendous organizational effort to organize the collection and back haul of empty containers, the handling of empty containers adds pressure to already congested ports [28]. Some ports have even refused to handle empty containers in an effort to keep congestion limited [29].

All these problems show us that an alternative to the transport solution is needed. The main problems addressed above which make transport chains unfavorable are not originating within a certain transport. That is because each individual leg bears the same uncertainties as in a direct transport. Yet, the problems become apparent at the seams of the different modes.

The choice of the transport mode is a complex decision which includes several criteria. Among those criteria, it is cost factor that has to be primarily considered. In fact, the cost factor was the most important criterion in studies of transport selection criteria in the last century. The transport cost depends upon the nature of the product range and its market, which varies from $2 \%$ (machinery) to $40 \%$ (food) of the recommended selling price of products. However, the average transport cost is between 5 and $6 \%$ of the recommended retail price of the product [14]. Transport price factors are evaluated as more important than other transport selection criteria by a high proportion of producers. The higher costs can be partially explained by factors such as topography, location, transport distances and limited domestic competition. One survey shows that even for exporters with products with a high value-to-weight ratio, only about $50 \%$ of them rate timing factors are as more important than transport price factors [8].

Express freight is a favored transport mode between the EU and Asia. Though it is not much quicker than normal air transport, some customers are still willing to pay a premium for fast, reliable delivery services. Indeed, express also indicates the safety aspect to the customer [17]. The EU has embraced "short-sea shipping" as a way to reduce pressure on the road and rail systems, especially in Western European countries, in order to build up a "win-win" relationship with their clients [11].

Though air and sea transport play an increasingly important role in the Europe-Asia transport market, intermodal transport with road is the only mode of transport which can offer an unbroken door-to-door service between Asia and Europe. It is true that rail is faster than road and more economical than air and air transport can offer the most effective way.
In fact, the new Silk Road has already been taken into consideration and is under construction. Thus China holds the key to progress in Asia. Germany holds the key to progress in the EU and has also made substantial steps forward in the construction and rehabilitation of road and rail links in its own territory [24]. Consequently, the fast sea-, air- and rail-based intermodal transport has been given priority, in addition to the direct air route.

With respect to trade routes, in early times there were well-known sea routes as well as the grand "Silk Road" linking Asia to Europe. At present, there is potential to extend this "silk road" to encompass Asia and Europe in one more or less coherent road and rail network. The project on pan-Europe and pan-Asian networks has already been launched under the auspices of EU and UNDP committees [11].

\section{RESEARCH METHOD}

\section{A. Desk-based research}

This research work has been carried out through desk-based research. Desk-based research means gathering information from a variety of sources including documents, reports, databases and the internet. Based on desk-based research, an overview of the current status of the transport chain between China and Germany can be presented. Furthermore, the critical factors for selection of the operational mode are discussed [18].

\section{B. The dicision making of transport modes}

The rational decision making as to a suitable transport mode is a complex process involving many criteria, especially for long-distance haulage transport. There are several criteria that have an influence on this decisionmaking process [27]. According to a content analysis by Cullinane and Toy (2000) the five most often considered criteria in the transport mode choice literature are [26]:

- Cost;

- Speed;

- Transit time reliability;

- Characteristics of the goods;

- Service.

These criteria are ranked according to their importance, with the transportation costs being the most important factor. For the comparison of different transportation modes it should always be considered that this factor is by far the most decisive for logistics managers [26].

Based on the selection mode by Slater (2007) [14], a transport mode selection framework for international distribution has been formulated by the authors (Figure 2). 


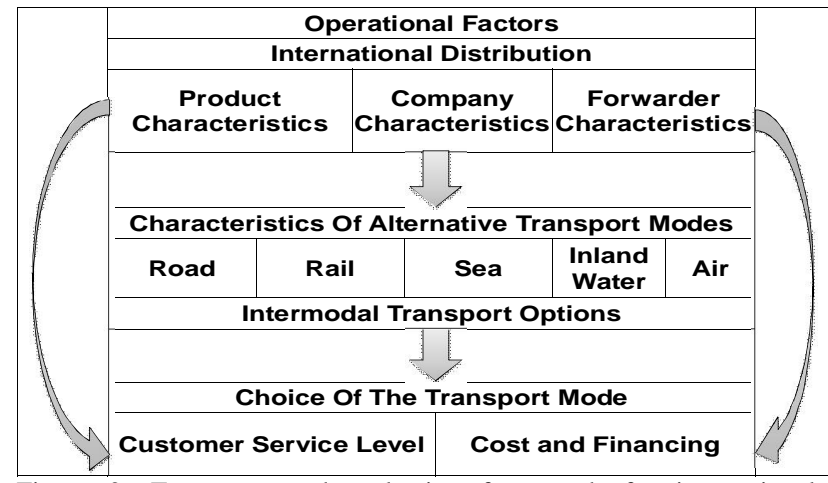

Figure 2: Transport mode selection framework for international distribution (Source: Authors with reference to Slater (2007) [14])

Generally, a consideration of each transport mode needs to identify its features, such as service, price, timing and transport security [8]. The selection of the mode is determined by numerous factors for international distribution. The option of the port for shippers, forwarders and destination port is affected by a large number of commercial conditions and customer service level. These elements can be classified into two distinct groups [14].

The operational factors consist of three elements: product characteristics, company characteristics and forwarder characteristics. Product characteristics describe the nature of the goods that need to be transported; they include the size, shape and weight of the product. Company characteristics describe the situation of the company shipping the goods as well as the company receiving the goods; they mean the manufacturing locations, warehouse locations, fragile nature of the financial situation, market dispersion and segmentation policy and the value marketing centres. The location could be of great importance here. Forwarder characteristics mean the consideration of factors such as service level, warehouse locations, transport route and partner relationship between road transport companies. The customer characteristics include geographical situation/location, delivery point, features, size of order, return loads, product utility/service level requirement, credit rating, competitors' rating, after-sales service requirements, elasticity of demand/product alternatives, type of sale (FOB/CIF/DDP), and product knowledge [18]. Furthermore, the geographical characteristics should be taken into account. In German topography, the port of Hamburg is in a unique position for international trade. According to 2009 German government statistics, air transportation is used especially for expensive goods such as electronics, food and some spare parts.

\section{SWOT analysis:}

The SWOT analysis, which enquires into strengths (S), weaknesses (W), opportunities (O) and threats (T), is a traditional way to search for insights into ways of realizing the desired alignment [8]. The SWOT analysis is useful as a decision-making tool and can be used in business strategy for industry and administration [2]. The SWOT analysis is a conceptual framework for further research into the combination of factors external to the environment and factors internal to the enterprise. Based on these variables the corresponding strategy can be obtained [8].

In this research, the SWOT analysis was used for the options air, sea and rail traffic. Following consideration of internal and external factors, the strengths, weaknesses, opportunities and threats are presented. With regard to the air transport and sea transport modes, the SWOT analysis was carried out for the transport chain between China and Germany. The results are summarized as follows.

\section{ANALYSIS AND RESULT}

\section{A. Marine Mode:}

Though marine transport plays an important role in international trade, especially for trade between China and Europe, the load volume is growing with logistics development based on increasing international trade between China and Germany. There are risks to be considered, such as political instability, hidden costs, lack of security and delays at borders due to the long-distance nature of Asian-European transport. Moreover, marine transport rates are often incorrectly compared with the rates for inland transport modes. For instance, comparing only the cost and time required for a container to be shipped from Shanghai port to Hamburg port by inland transport could lead to the incorrect conclusion [24].

Rail and lorry transport is subsidiary traffic mode when the total successful routes are considered. Trains and bus businesses dramatically improve speed and services on their medium- and long-distance routes between China and Europe, attracting customers away from the marine mode. Secondly, the cargo security issue, with its risk of piracy has to be considered because of the long range and lengthy shipping time. Therefore, the marine mode application is suitable for machinery and vehicles.

TABLE III. SWOT ANALYSIS OF MARINE MODE

\section{SWOT of M arine M ode between China and Ger many}

\begin{tabular}{|l|l|l|l|}
\hline $\begin{array}{l}\text { S\& O } \\
\text { strategy: }\end{array}$ & $\begin{array}{l}\text { S: } \\
\text { keep up } \\
\text { the cost } \\
\text { advantage } \\
\text { low transport } \\
\text { cost, suitable } \\
\text { for the } \\
\text { product with } \\
\text { large volume }\end{array}$ & $\begin{array}{l}\text { Slow, Surcharges, not } \\
\text { flexible, }\end{array}$ & $\begin{array}{l}\text { Speed up with } \\
\text { high technology } \\
\text { and logistical } \\
\text { development (such } \\
\text { as selection of the } \\
\text { optimal transport } \\
\text { link or reduction } \\
\text { of the transit } \\
\text { shipment) }\end{array}$ \\
\cline { 2 - 3 } & $\begin{array}{l}\text { O: } \\
\text { globalization, } \\
\text { continually } \\
\text { growing trade } \\
\text { volume } \\
\text { between } \\
\text { China and } \\
\text { Germany }\end{array}$ & $\begin{array}{l}\text { Teplacement by other } \\
\text { transport modes, new } \\
\text { problem with transport } \\
\text { security, fuel prices due } \\
\text { to global demand for } \\
\text { energy, empty backhaul } \\
\text { of containers due to } \\
\text { imbalanced trade }\end{array}$ & \\
\hline
\end{tabular}

(Source authors [30])

\section{B. Air Mode:}

The Chinese airline industry is growing faster than Chinese GDP is increasing, and the trend will continue in next five years. Because worldwide deregulation makes the skies more accessible, route agreement is easier to achieve [2]. The air mode is flexible, based on the direct and indirect air transportation link between China and 
Germany. The express option is more in favour recent years as customers are tending to be less price conscious and prefer to choose high quality service.

The transport industry but especially the airline sector is conditioned by oil prices. Thus, the air mode application is suitable for urgent shipments, for example, communications instruments, technological equipment and clothing.

TABLE IV. Swot ANALYSIS OF AIR Mode

\section{SW OT of Air M ode between China and Germany}

\begin{tabular}{|l|l|l|l|}
\hline $\begin{array}{l}\text { S\& O } \\
\text { strategy: }\end{array}$ & S: & W: & $\begin{array}{l}\text { W \& T } \\
\text { Strategy: }\end{array}$ \\
$\begin{array}{l}\text { Retain the } \\
\text { service level, } \\
\text { Reliable, } \\
\text { expansion of } \\
\text { flexible } \\
\text { the current } \\
\text { market } \\
\text { share, focus } \\
\text { on the lead } \\
\text { time and } \\
\text { safety }\end{array}$ & $\begin{array}{l}\text { Glost, large pieces } \\
\text { or heavy load } \\
\text { limits shortage of } \\
\text { flight capacity } \\
\text { trade volume }\end{array}$ & $\begin{array}{l}\text { Reduce the } \\
\text { logistic cost, } \\
\text { improvement } \\
\text { of the load } \\
\text { volume of the } \\
\text { aspecially for the } \\
\text { airplane. }\end{array}$ \\
\cline { 2 - 3 } & $\begin{array}{l}\text { Tigh technological } \\
\text { product trade } \\
\text { between Asia and } \\
\text { EU, especially for } \\
\text { China and Germany }\end{array}$ & $\begin{array}{l}\text { Replacement } \\
\text { other transport } \\
\text { mode, } \\
\text { fluctuation of the } \\
\text { oil price, global } \\
\text { sea pollution, } \\
\text { capacity limits of } \\
\text { Seaports }\end{array}$ & \\
\hline
\end{tabular}

(Source authors [30])

\section{Train Mode}

The train route between Asia and Europe has been called the emergence of a modern Silk Road. Although the projected Eurasian Land Bridge is still under discussion, it is necessary to make a SWOT analysis due to the large market demand and the huge advantage. Train transportation can substitute the other two modes. It can significantly reduce the empty backhaul of containers compared to sea and air transport. It can reduce global sea pollution which is partially caused by a rapid growth in transport. And it is more flexible and reliable than sea transport, more economical for larger volumes than air transport. However, since this train will cross several countries, there are technical problems like the standard gauge of the rail, new regulations and the administration challenges and the huge investment cost. The application of the train mode, however, can cover a wide field, such as machinery and vehicles, food and clothing.

\section{Influencing factors for transport mode selection:}

Obviously, there are big differences in both speed and costs between the sea and air modes. With regard to the transport offered to Chinese corporations in Germany, while the lead time for intermodal transport with sea is about 30 days from Hong Kong to Germany, for air transport it is three days. However, as the lead time is decreased, the cost is increasingly raised. Obviously, timing and cost are the most essential influencing factors. Table 6 is from a Chinese telecom technology corporation in Germany. In practice with logistics costs based on weight/volume of cargo, the basic principle is shipment by air at US\$8/kg, US\$150/volume by sea or by truck [15].
TABLE V. SwOT ANALYSIS OF TRAIN MODE

\begin{tabular}{|c|c|c|c|}
\hline \multicolumn{4}{|c|}{ SW OT of Train M ode between China and Germany } \\
\hline \begin{tabular}{|l} 
S\& 0 \\
strategy: \\
Focus on and \\
stabilize the \\
service \\
quality, \\
reduce the \\
operation \\
cost, \\
improved the \\
management \\
and \\
organization. \\
Focus on the \\
right product \\
for the right \\
market at the \\
right time \\
and at the \\
right price.
\end{tabular} & $\begin{array}{l}\text { S: } \\
\text { Faster than marine } \\
\text { transport, lower cost } \\
\text { than Air transport, } \\
\text { Safe, } \\
\text { Reliable, } \\
\text { Flexible, avoid the } \\
\text { Empty container } \\
\text { backhaul } \\
\text { O: } \\
\text { Globalization, } \\
\text { continually growing } \\
\text { trade volume the } \\
\text { high technological } \\
\text { product trade } \\
\text { between Asia and } \\
\text { Euro especially for } \\
\text { China and Germany, } \\
\text { sustainable } \\
\text { alternative of martin } \\
\text { transport, EU East- } \\
\text { Expansion }\end{array}$ & $\begin{array}{l}\text { W: } \\
\text { Problem with } \\
\text { standard gauge } \\
\text { of the trail, } \\
\text { regulation and } \\
\text { administration, } \\
\text { high transport } \\
\text { cost, }\end{array}$ & $\begin{array}{l}\text { W \& T } \\
\text { str ategy: } \\
\text { Improvement } \\
\text { the } \\
\text { international } \\
\text { corporation, } \\
\text { build the } \\
\text { standard and } \\
\text { unified } \\
\text { operation } \\
\text { system, the } \\
\text { speed up with } \\
\text { the high } \\
\text { technology. }\end{array}$ \\
\hline
\end{tabular}

(Source authors [30])

TABLE VI. COMPARISON OF TRANSPORT MODE BASED ON THE TIMING- AND THE COST FACTOR [16]

\begin{tabular}{|c|c|c|c|c|}
\hline Departure & Destination & Mode & $\begin{array}{l}\text { Required } \\
\text { (Door To } \\
\text { Door) Days }\end{array}$ & Cost \\
\hline Shenzhen & Hamburg & Sea & 34 & $\begin{array}{c}\text { 150USD/Vol } \\
\text { ume }\end{array}$ \\
\hline Hong Kong & Hamburg & Sea & 33 & $\begin{array}{c}\text { 150USD/Vol } \\
\text { ume }\end{array}$ \\
\hline Hong Kong & Frankfurt & $\begin{array}{l}\text { Air Direct: } \\
\text { HKG- FRA }\end{array}$ & 3 & 8USD/KG \\
\hline China & Germany & Trail Direct & 15 & $\begin{array}{c}\text { Results to be } \\
\text { calculated }\end{array}$ \\
\hline
\end{tabular}

Source: Logistics commercial offer from the forwarder, information from a Chinese technologies company in Austria, unpublished [30].

The process of selecting the appropriate transport mode is an important business decision. The price and timing factors are the most important selection criteria. The product and customer characteristics play an important role for transport mode selection today. In addition, due to the long distance between China and Germany, the possibility of product damage in transit is high. Choosing air transport can significantly reduce or even prevent transport damage.

Profitability can be enhanced by effective management of the transport function, through cost reduction and service improvements. Table 7 indicates numerous routings for the forwarders to organize air transport, which leads to flexibility. The air transport route is quite flexible due to the booming international trade between China and Europe.

TABLE VII. COMPARISON OF THE AIR TRANSPORT ROUTING FOR THE ELECTRO TECHNOLOGY PRODUCTS [15] 


\begin{tabular}{|c|c|c|c|c|c|}
\hline \multicolumn{6}{|c|}{ Air Transport route from Hongkong to Germany } \\
\hline \multicolumn{3}{|c|}{ Forwarder A } & \multicolumn{3}{|c|}{ Forwarder B } \\
\hline \multicolumn{6}{|c|}{$\begin{array}{c}\text { Product Characteristic: Electro technology Equipment } \\
\text { Product Characteristic: Terminal Product }\end{array}$} \\
\hline \multicolumn{6}{|c|}{$\begin{array}{c}\text { Route planning } \\
\text { (estimated departure time and arrival time of every port) }\end{array}$} \\
\hline & & & $10-12-15$ & ETA & HKG \\
\hline & & & $10-12-16$ & ETD & HKG \\
\hline $10-12-14$ & ETA & HKG & $10-12-17$ & ETA & HHN \\
\hline $10-12-15$ & ETD & HKG & $10-12-18$ & ETD & HHN \\
\hline $10-12-16$ & ETA & FRA & $10-12-19$ & ETA & FRA \\
\hline & & & \begin{tabular}{|l|}
$10-05-24$ \\
\end{tabular} & ETD & HKG \\
\hline & & & $10-05-26$ & ETD & HKG \\
\hline & & & $10-05-27$ & ETA & LUX \\
\hline $10-05-07$ & ETD & HKG & $10-05-27$ & ETD & LUX \\
\hline $10-05-08$ & ETA & FRA & $10-05-27$ & ETA & FRA \\
\hline $10-05-09$ & ETA & FRA & $10-06-01$ & ETD & FRA \\
\hline $10-05-10$ & ETA & HAM & $10-06-02$ & ETD & DUI \\
\hline
\end{tabular}

Source: Logistics commercial offer from the forwarder, information from a Chinese technologies company in Austria, unpublished [30].

Finally, a reliable relationship with the forwarder is also vital for route selection, as long-term cooperation stabilizes the security of the delivery, which can be even more important than the price and timing factors. Furthermore, in the choice of mode of transport, the route, cost and service factors (including timing, reliability and urgency, damage avoidance, loss and theft, etc.) all have to be considered for the transport valuation.

Air freight is normally recognized by most companies as being primarily a means of achieving urgent shipments and is defined as a high-priced mode of transport. This transportation mode is preferable for the markets of communication instruments, technological equipment or fashion items. In fact, for some high-volume light products, taking the air mode can reduce total distribution costs. Through the combination of speed, reliability, frequency and the first-class "environment" of air transport, it results in a high quality service leading to less damage and subsequent reductions in protective packaging requirements [17]. The cost advantages of taking air transport stem from a number of features. Further, the reduction in lead-time makes for a reduction in in-transit inventory, especially speedier.

Express freight is one of the greatest recent evolutions in transport. Though it is not much quicker than normal air transport, some customers are still willing to pay a premium for fast, reliable delivery services. Indeed, express also indicates safety to the customer [17].

\section{CONCLUSION}

Choosing the right transport mode is a complex decision-making process involving many internal and external factors, each one of which offers many opportunities and challenges. This paper analyses and compares the transport chains between China and Germany. The characteristics of alternative transport modes are determined by the three operational factors: product, company and forwarder characteristics. Choosing different characteristics of alternative transport modes can affect the customer service level, cost level and financing. Intermodal transport with air and marine links is the main option between China and Germany; development of rail transport should be urged as well. The most vital factors relating to route options are for example price, timing, level of service and relationship with forwarder, among others.

The final selection will depend upon many objective factors, but especially depend upon management's skill in determining and quantifying the significant options available, what will be achieved only by a thorough and systematic approach to the problem. A successful decision will be reached only by a systematic and accurate approach to the transport problem. This research is limited, since the possibility of the train route is still to be developed and is untested; the Eurasian Land Bridge is still under construction; more secondary data should be used to validate the research in the future.

\section{ABBREVIATION}

$\begin{array}{ll}\text { CEE } & \text { Central and Eastern European } \\ \text { EATL } & \text { Euro-Asian Transport Links } \\ \text { EU } & \text { European Union } \\ \text { SWOT } & \begin{array}{l}\text { Strengths Weaknesses Opportunities Threats - } \\ \text { analysis }\end{array} \\ \text { TAR } & \text { Trans-Asian Railway } \\ \text { TEM } & \text { Trans-European Motorway } \\ \text { TEN-T EA } & \text { Trans-European Transport Network Executive } \\ & \text { Agency } \\ \text { TEN-T } & \text { Trans-European Network for Transport } \\ \text { TER } & \text { Trans-European Railway } \\ \text { TRACECA } & \text { Transport Corridor Europe-Caucasus-Asia } \\ \text { TSR } & \text { Trans-Siberian Railway } \\ \text { USA } & \text { United States of America }\end{array}$

\section{REFERENCE}

[1] A. Liliopoulou1,"Trans Siberian Railway: from inception to transition", "European Transport", 2005, pp. 46-56.

[2] Ahmed A.M., "SWOT analysis for Air China performance and its experience with quality", Benchmarking: An International Journa,Vol. 13 No. 1/2, 2006, pp. 160-173.

[3] Bookbinder J.H.and Tan C.S., "comparision of asian and european logistics systems", Int. Journal of Physical Distribution \& Logistics Managemen Vol.33 No.1, 2003, pp. 35-58.

[4] Babbar, S. and Prasad, S., "International purchasing, inventory management and logistics research", International Journal of Physical Distribution \& Logistics Management, Vol.28 No.6, 1998, pp. 403-433.

[5] Cook, W.R., "Transport decisions of certain firms in the Black Country", Journal of Transport Economics and Policy, Vol. 1 No. 2, 1967, pp. 326-44.

[6] Philipp Ehmer, Stefan Heng and Eric Heymann, "Logistik in Deutschland", in: Deutsche Bank Research , Aktuelle Themen 432, 2008, Print: ISSN 1430-7421. pp. 1-16.

[7] Gennady Bessonov, "Trans-Siberian Route: an Effective Transport Link between Europe and Asia", "International Delegate Conference Making the Intermodal Connection: The Role of Terminals", 2010, pp,1-6, published under: http://www.freightexpo.net/images/Bessonov.pdf (2010.12.31)

[8] E.L. Pedersen, "The transport selection criteria of Norwegian exporters", International Journal of Physical Distribution \& Logistics Management, Vol. 28 No. 2, 1998, pp. 108-120.

[9] EU Commission (2010), Web: http://www.eeas.europa.eu/china/index_en.htm (2010.08.31).

[10] TRACECA, "How TRACECA started", Web: http://www.traceca-programme.eu/\%20en/traceca/history-oftraceca/ $(2011.01 .01)$ 
[11] John Kidd, "From pre-Medieval to post-Modern times Logistics routes and their modalities have not changed much", Management Decision, Vol. 43 No. 9, 2005, pp. 1249-1261

[12] Bundeszentrale für politische Bildung (BPB), Web: http://www.bpb.de/wissen/6UIV8O,0,0,Handelspartner.html (2010.12.31)

[13] Frankfurt Airport, Web: http://www.frankfurtairport.de/content/frankfurt_airport/de/news0/20100902dritte_lufthansa-a380.html (2010.12.31)

[14] Slater A. G. , "Choice of the Transport Mode","New Horizons", pp. 72-91, 2007, published.

[15] Seo, J.-Y., "Perception-building vital for hub plan", The Korea Times, 25 November, p. 9.Silkroad Foundation (1997-2000), "Marco Polo and His Travels", 2003, Web: www.silkroad.com/artl/marcopolo.html (accessed May 2004).

[16] T. Wimmer, "Logistic in China", "the Wimmer u.a. Logistik in China", 2008, pp. 39-42, published.

[17] Unknown Author, "What Transport Arrangements Should We Make? ", EFFECTIVES LOGISTICS MANAGEMENT, pp. 4649, published.

[18] Tong J., Wang X.-N., Wen H.-T. and Kummer S, "Analysis and Comparison of Transport Chain between China and Austria", Proc. IEEE 2010 International Conference on Logistics Engineering and Intelligent Transportation Systems (LEITS2010), IEEE Press, Nov.2010, pp.141-146.

[19] United States Fortune (2009), http://www.stats.gov.cn/tjsj/qtsj/gjsj/2009/t20100415 402634719. $\underline{\mathrm{htm}}(2010.12 .31)$.

[20] Statistik Germany, Landerprofil China, http://www.destatis.de/jetspeed/portal/cms/Sites/destatis/Internet/ DE/Navigation/Publikationen/Fachveroeffentlichungen/Laenderpr ofile,templateId=renderPrint.psml_nnn=true (2010.12.28)

[21] Air Cargo Week (ACW), Web: http://www.azworldairports.com/azworld/p1600.cfm (2010.12.20).

[22] National Bureau of Statistics of China, Web: http://www.stats.gov.cn/tjsj/qtsj/gjsj/2009/index.htm (2010.12.31).

[23] Boris E. Lukov, "The Transsiberian Rail Corridor: Present Situation, and Future Prospects", pp. 1-22. under: http://www.promit-

project.net/UploadedFiles/Events/Pres_Seminar_7thWorkshop/Lu kov_CCTT_TSR.pdf (2010.12.28)

[24] Statistische Bundesarmt Deutschland, Web: http://www.destatis.de/jetspeed/portal/cms/Sites/destatis/Internet/ DE/Navigation/Publikationen/Fachveroeffentlichungen/Laenderpr ofile,templateId=renderPrint.psml_nnn=true $(2010.12 .31)$

[25] Donner R. and Tong J. (2011), “Transport Chain Management - Assessing the Impact of Transport Chain Performance on Total Supply Chain's Cost, pp. 2-6, unpublished.

[26] Cullinane K. / Toy N. (2000): Identifying influential attributes in freight route/mode choice decisions: a content analysis, in: Transportation Research Part E, Vol. 36 (2000), No. 1, pp. 41-53, 2000 .

[27] Meixell M. / Norbis M. (2008): A review of the transportation mode choice and carrier selection literature, in: The International Journal of Management, Vol. 19 (2008), No. 2, pp. 183-211, 2008

[28] Theofanis S. / Boile M. (2008): Empty marine container logistics: facts, issues and management strategies, in: GeoJournal, Vol 74 (2009), No. 1, pp. 51-65, 2008

[29] Barnard B. (2007): Bent but not broken, in: Journal of Commerce, 4/30/2007, Vol. 8, Iss. 17, p 24-28, 2007.

[30] Tong J., Wang X.-N., Wen H.-T. and Kummer S (2011), "Transport Chain between China and Germany: a SWOT Analysis.. Proc. 2011 International Conference on Manufacturing and Industrial Engineering, IEEE Press. Feb. 2011, pp.55-61, 2011.

[31] European Commission (2010): TEN-T / Transport infrastructure. What do we want to achieve?, Web: http://ec.europa.eu/transport/infrastructure/index_en.htm (2010.12.28)

Jian TONG was born in 1971 in Sichuan, China. She was awarded a degree of Bachelor of Engineering in Xi' an Jiaotong University in China in 1993. In 2005 she awarded a degree of Mag.rer.soc.oec. (equivalent to MBA) in the discipline Business Administration from the Vienna University of Economics and Business in Austria (WU Wien Austria). In 2011 she was awarded a degree of Dr. rer. soc. oec. (equivalent to $\mathrm{PhD}$ ) in the discipline Business Administration majoring in transport economics and logistics management from the WU Wien Austria.

She has industry background in energy engineering in China. Since 2006 she is researcher and teaching assistant at Department of Transport and Logistics Management at WU Wien Austria. She has been involved in a range of logisticsand transport-related research projects. Her main research focuses on decision-making process in supply chain management with particular reference to the Chinese logistics markets, as well as logistics and supply chain strategic management and performance evaluation.

Dr. Tong received an award "young faculty 2008" of WU Wien Austria to reward excellent teaching. In 2010 she received the best paper award of Chinese journal of management science. Dr.Tong can be contacted at: jian.tong@wu.ac.at.

Haitao WEN was born in 1975 in Jilin, China. She was awarded a Bachelor degree of economics in Jilin Agricultural University in 1997. In 2000 she was awarded a Master degree of management in Jilin Agricultural University. In 2007 she was awarded a PhD in Economics from Jilin University, China. In 2009 she received a one year grant from EPN for postdoctoral research in Department of Transport and Logistics Management at WU Wien Austria.

She had a special experience after she graduated in June 2000. She took service to be a civilian drillmaster in Quartermaster University of People's Liberation Army of China. And then, she began to teach and research logistics management, especially focus on national economy mobilization and defense acquisition management. She received some research project which funded by Ministry of Logistics or university. But in 2004, due to large-scale disarmament in China, her inaugural university was abrogated from Army and most of the employees were employed by Jilin University. Fortunately, Logistics research direction was remained by creating Logistics Department. In 2008, she got Associate Professor's position. Therefore, her main research field still focuses on performance evaluation and demand chain management in agri-food supply chain, as well as procurement management and supply chain optimization.

Dr. Wen received the best paper award of Chinese journal of management science in 2010. Dr.Wen can be contacted at: wenht@jlu.edu.cn.

Xuemei FAN was born in 1971 in Jilin, China. She was awarded a degree of Bachelor of Science majoring in maths in Northeast Normal University in China in 1993. In 2003, she awarded the master's degree of Management majoring in agricultural economics management from People's Liberation Army Quartermaster University in China. Now she is a ph.D 
candidate of agricultural systems engineering in School of Biological and Agricultural Engineering, Jilin University.

She has been working in Jilin University for nineteen years since 1993, served as dean of logistics department and in charge of graduate student. Her main research focuses on agricultural logistics and purchasing management. Her published articles include "Research on development and strategy of agriculture product logistics in Jilin province", "Research on agricultural product supply chain performance evaluation based on logistics ability".

Associate Prof. Fan was awarded as expert of Jilin Logistics Association, executive director of Changchun Logistics Association and senior reviewer of Chinese logistic company grading. Associate Prof. Fan is the corresponding author and can be contacted at: fxm@jlu.edu.cn.

Prof. Dr. Sebastian KUMM ER is Chair of the Department of Transport and Logistics Management at WU Wien Austria and Director of the European section of the MIT Forum Supply Chain Innovation.

$\mathrm{He}$ is visiting professor at universities in China and has been visiting professor in Vietnam (Hanoi), Russia (Moscow), Ukraine (Kiev), Germany (Hamburg, Marburg, Zittau) and Austria (Leoben, Krems). He has published more than 140 publications. His research focuses on logistics management, supply chain management, Logistics and supply chain performance measurement as well as on integration of transport systems in logistics networks, economical analyses in investments in transport infrastructure and vehicles. He works as a consultant and management trainer for companies and government bodies. Prof. Kummer can be contacted at: Sebastian.kummer@wu.ac.at. 